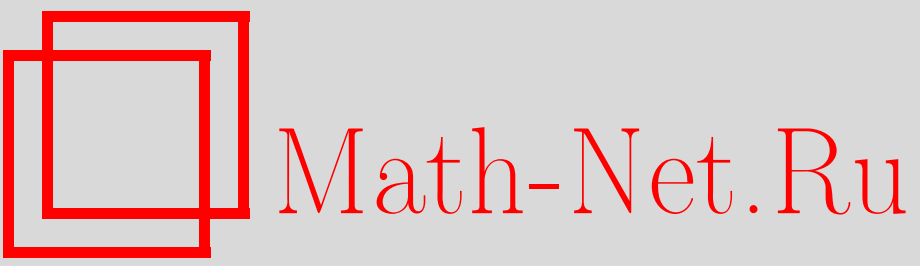

А. Л. Лукашов, Д. И. Трубецков, П. Л. Ульянов, А. П. Хромов, Девятая Саратовская зимняя школа "Современные проблемы теории функций и их приложения", УМН, 1998, том 53, выпуск 2, 185-186

DOI: https://doi.org/10.4213/rm1613

Использование Общероссийского математического портала Math-Net.Ru подразумевает, что вы прочитали и согласны с пользовательским соглашением

http://www.mathnet.ru/rus/agreement

Параметры загрузки:

IP: 3.95 .254 .165

26 апреля 2023 г., 16:09:27 


\title{
ДЕВЯТАЯ САРАТОВСКАЯ ЗИМНЯЯ ШКОЛА “СОВРЕМЕННЫЕ ПРОБЛЕМЫ ТЕОРИИ ФУНКЦИЙ И ИХ ПРИЛОЖЕНИЯ"
}

\begin{abstract}
С 26 января по 1 февраля 1998 года в Саратове проходила Девятая Саратовская зимняя школа "Современные проблемы теории функций и их приложения", организованная Московским государственным университетом им. М. В. Ломоносова, Математическим институтом РАН им. В. А. Стеклова и Саратовским университетом им. Н. Г. Черньшевского при финансовой поддержке Российского фонда фундаментальных исследований. В работе девятой школы приняли участие 128 математиков из 31 города России, Армении, Казахстана и Украины. Среди участников школы были два члена-корреспондента РАН, один академик АН Армении, 35 докторов наук, 48 кандидатов наук. Оргкомитет школы возглавили член-корреспондент РАН П. Л. Ульянов (председатель), член-корреспондент РАН Д. И. Трубецков (зам. председателя), профессор А.П. Хромов (зам. председателя), академик РАН С. М. Никольский, член-корреспондент РАН Б. С. Кашин, профессор, академик МАН ВШ Е.П. Долженко, профессора Б. И. Голубов, Ю. Ф. Коробейник, Ю. В. Покорньй, Д. В. Прохоров, А. М. Седлецкий, Ю.Н. Субботин, В.А. Юрко, доцент А. Л. Лукашов (секретарь).

В связи с приближающимся 70-летием П. Л. Ульянова было прочитано 4 лекции о его вкладе в развитие теории функций: Е. П. Долженко (Москва) "Об $A$-интеграле Коши", Б. С. Кашин (Москва) "О работах П. Л. Ульянова по теории ортогональных рядов", М. К. Потапов (Москва) "О вложении классов функций", А. А. Талалян (Ереван) "П. Л. Ульянов и развитие метрической теории функций в СССР". П. Л. Ульянов поделился с участниками школы своими воспоминаниями.
\end{abstract}

Для целостного представления о современном состоянии и существующих приложениях теории функций и указания возможных путей ее дальнейшего развития Оргкомитет заказал лекции продолжительностью 1 час. Было прочитано 7 лекций:

1. А. С. Белов (Иваново) "О некоторых неотрицательных тригонометрических полиномах с целыми коэффициентами".

2. С. И. Дудов (Саратов) "Максимин функции разности аргументов и его приложения".

3. В.И. Лебедев (Москва) "Экстремальные многочлены и оптимальные алгоритмы".

4. С. Р. Насыров (Казань) "Об одной задаче М. А. Лаврентьева".

5. А.М. Олевский (Москва) "Целочисленные и "почти" целочисленные сдвиги".

6. Е. С. Половинкин (Москва) "Сильно выпуклые множества и функции. Приложение теории игр".

7. И. И. Шарапудинов (Махачкала) "Приближение дискретных функций и многочлены, ортогональные на дискретных сетках".

Занятия в школе проходили в две смены. В первой половине дня читались лекции, после обеда работали три секции, на которых были заслушаны 25 докладов и 71 научное сообщение. Список докладов таков:

1. В. М. Бадков (Екатеринбург) "Порядок кругового параметра в случае обобщенного веса Якоби".

2. В.И. Бердышев (Екатеринбург) "Производная уклонения в задаче навигации".

3. А.П. Буланов (Обнинск) "О степени бесконечной кратности с коэффициентами, имеющими поочередно два значения". 
4. В.В. Власов (Москва) "О некоторых спектралњных вопросах, возникающих в теории функционально-дифференциальных уравнений".

5. Г. Г. Геворкян (Ереван) "О рядах Уолша с монотонными коэффициентами".

6. Б.И. Голубов (Долгопрудньй) "Аналоги операторов Харди и Харди-Литлвуда, связанные с преобразованием Уолша".

7. Е.П. Долженко (Москва) "О граничном поведении производных полианалитических функций".

8. М. И. Дьяченко (Москва) "О преобразованиях Фурье кусочно-монотонных функций многих переменных".

9. Б. С. Кашин (Москва) "О свойствах подматриц для некоторых классов ортогональных матриц"

10. С.В. Конягин (Москва) "Рациональные тригонометрические суммы с показательной функцией".

11. Т. П. Лукашенко (Москва) "Обобщенные системы разложения, подобные ортогональным".

12. С. Ф. Лукомский (Саратов) "О расходимости почти всюду двойных рядов Уолша".

13. Б.П. Осиленкер (Москва) "Аналог формулы следа для решений уравнения Лакса".

14. В.А. Осколков (Москва) "О некоторых базисах в пространствах целшхх функций".

15. Д. В. Прохоров (Саратов) "Оценки линейных функционалов в классе однолистных функций, близких к тождественной".

16. К.М. Расулов (Смоленск) "О решении неклассической задачи типа Дирихле для полианалитических функций в областях с кусочно-аналитическими границами".

17. В.А. Родин (Воронеж) "О преобразовании Харди и Белмана в пространствах Орлича, $\mathrm{BMO}$ и $\operatorname{Re} H^{1 "}$

18. А.М. Седлецкий (Москва) "Близкие системы экспонент".

19. В.И. Семенов (Кемерово) "Некоторые новые и старые задачи квазиконформных отображений в неравенствах".

20. Ю.Н. Субботин (Екатеринбург), С.А. Теляковский (Москва) "Точные значения относительных поперечников".

21. Ю.Н. Субботин (Екатеринбург), Н. И. Черных (Екатеринбург) "Базисы в пространствах гармонических функций".

22. А. П. Терехин (Саратов) "Приближение сферическими аналогами тригонометрических сумм Фурье".

23. Н.Н. Холщевникова (Москва) "Обобщенная теорема Валле-Пуссена для системы Уолша".

24. А. П. Хромов (Саратов) "Об обращении интегральных операторов с ядрами, разрьвными на диагоналях".

25. В.А. Юдин (Москва) "Экстремальные расположения точек на сфере".

Изданы тезисы школы, кроме того, осуществлено издание трудов 5-й и 6-й Саратовских зимних школ по теории функций и приближений.

По общему мнению, школа прошла успешно, хотя болшшему представительству молодых ученых, аспирантов и студентов помешали финансовые трудности, переживаемые сейчас российской наукой.

Участники школы решили следующую 10 -ю школу в 2000 году посвятить итогам развития теории функций во втором тысячелетии и обсуждению основных проблем, стоящих перед теорией функций. Оргкомитету поручено подготовить список основных докладов на 10-й школе и начать необходимую подготовительную работу.

А. Л. Лукашов, Д. И. Трубечков, П. Л. Ульянов, А. П. Хромов 